\title{
Kentsel Ekoturizm Açısından Isparta Kent İnsanının Talep ve Eğilimleri
}

\author{
Fatma Gözde AKKUŞ ${ }^{1 *}$, Atila GÜL ${ }^{2}$ \\ ${ }^{1}$ Süleyman Demirel Üniversitesi, Fen Bilimleri Enstitüsü, Peyzaj Mimarlığı Ana Bilim Dalı, 32260, Isparta, Türkiye. \\ ${ }^{2}$ Süleyman Demirel Üniversitesi, Mimarlık Fakültesi, Peyzaj Mimarlığı Bölümü, 32260, Isparta, Türkiye. \\ *e-mail: fatmagozdeakkus09@gmail.com
}

Öz

Sürdürülebilir turizmin ifadesi olan ekoturizm kentlere farklı bir değer katmaktadır. Bu değer ise kentsel mekanları ve yaşam kültürünü zenginleştirirken, sosyal, ekonomik, ekolojik ve çevresel katkıları da beraberinde getirmektedir. Kentsel ekoturizm, yöresel değerlerin önem kazanması, yöresel ve bölgesel ekonominin canlanması, insanların yeni yerler keşfetmesi, yerel deneyimlerin artması, farklı kültürdeki insan topluluklarının bir araya gelmesi, doğal çevreye sahip çıkma bilincinin kazanılması gibi pek çok katkılar sağlamaktadır. Çalışmanın amacı Isparta kentinin kentsel ekoturizm potansiyelinin ortaya konulması ve kent insanının talep ve eğilimlerinin belirlenmesi ve analizidir. Bu kapsamda Isparta kentinin kentsel ekoturizm açııından mevcut kaynak değerleri belirlenmiş, kent insanına ( $n$ : 409) yapılan anket çalışması ile kentsel ekoturizmine yönelik talep ve eğilimler belirlenmiş ve GZFT analizi ile mevcut durum tespiti yapılmıştır. Elde edilen sonuçlara göre, ekoturizmin yapılma nedeni doğayı keşfetme ve bazı rekreasyonel etkinliklerde (doğa yürüyüşü, dağ bisikleti ile gezinti ve fotoğraf çekme vb.) bulunma olarak belirtilmiştir. Özellikle kentsel açık yeşil alanların ekoturizm etkinlikler için en uygun alanlar olduğu belirlenmiştir.

Anahtar Kelimeler: Turizm, kentsel ekoturizm, sürdürülebilir turizm, Isparta, yeşil alanlar, peyzaj planlama.

\section{Demands and Tendencies of Isparta Urban People in Terms of Urban Ecotourism}

\begin{abstract}
The city of Isparta, which is the center of the Lakes Region in the Mediterranean Region, has a rich potential in terms of historical, archaeological and cultural values. Urban ecotourism provides many contributions such as gaining importance of local values, reviving local and regional economy, discovering new places, increasing local experiences, gathering of human communities from different cultures, and gaining the awareness of protecting the natural environment. In this study, the potential of the city of Isparta in terms of urban ecotourism was determined, the demands and trends for urban ecotourism were determined with a survey conducted to urban people (n: 409) and the current situation was determined with SWOT analysis. According to the results, the reason for ecotourism was stated as exploring nature and participating in some recreational
\end{abstract}

Atıf/Citation: Akkuş, F.G. ve Gül, A. (2020). Kentsel Ekoturizm Açısından Isparta Kent İnsanının Talep ve Eğilimleri. Mimarlık Bilimleri ve Uygulamaları Dergisi, 5(2), 181-200.

DOI: $\underline{10.30785 / \mathrm{mbud} .758514}$ 
activities (trekking, mountain biking and taking photographs, etc.). It has been determined that especially urban green areas are preferred as the most suitable areas for ecotourism activities.

Keywords: Tourism, urban ecotourism, Isparta, sustainable tourism, green areas, landscape planning.

\section{Giriş}

Hızla büyüyen sektörlerden biri olan turizm, günümüz dünyasında çok hızlı bir değişim göstermektedir ve çok önemli bir ekonomik gelirdir. Sürdürülebilir kalkınmanın önemi ile turizmde doğaya dayalı faaliyetler artmış, doğa için önemli alternatif sürdürülebilir turizm türleri ortaya çıkmıştır (Kasalak, 2015).

Ekoturizm kavramı, ilk kez Ceballos-Lascurain tarafından 1983 yılında kullanılmıştır (Cosmescu ve Cosmescu, 2007). 2002 yılı "Dünya Ekoturizm Yıı” olarak ilan edilmiştir. Ardından Birleşmiş Milletler Çevre Programı, Dünya Turizm Örgütü, Quebec Turizm Teşkilatı ve Kanada Turizm Komisyonu tarafından "Dünya Ekoturizm Zirvesi" gerçekleştirilmiştir. 19-22 Mayıs tarihinde Kanada'nın Quebec eyaletinde, 138 ülkeden gelen 1100 delegenin katılımıyla gerçekleştirilen Zirve'de, tüm ülkelerin benimsediği bir ekoturizm tanımı belirlenerek, ortak ekoturizmin ilke ve prensipleri benimsenmiştir (Bekdemir ve Elmacl, 2014; Buckley, 2013; Gheorghe ve Udrescu, 2018; Kaplan, 2013).

Gül ve Özaltın (2007b)'a göre ekoturizm türleri;

- Yaban hayatı gözlem ve inceleme

- Mağara, kanyon, peribacaları, şelale gibi jeomorfolojik oluşumları gözlem ve inceleme

- Bitki gözlem ve inceleme

- Tarihi, arkeolojik, dinsel ve geleneksel, kültürel obje ve alanların gözlem ve inceleme

- Ekoturizm tabanlı doğa sporları şeklinde ifade edilmektedir.

Kentsel ekoturizmi, ilk olarak Blackstone Corporation (1996) tarafından önerilmiş ve kentsel alanlara yapılan sürdürülebilir seyahatler edilmesi olarak kabul edilmiştir. 2004 yılında Kanada'da yapılan Kentsel Ekoturizm "Urban Ecotourism Conference" adlı konferansta, Kent Ekoturizmi; Şehirlerin korunmasına yönelik faaliyetleri ve şehirlere yapılan bir doğa seyahatidir. Kent ekoturizmi, aslında kent doğal ekosistemine saygı duyan bir turizm anlayışı olup kentin doğal ve kültürel kaynak değerlerinin keşfedilmesi ve gezilmesi olarak algılanmaktadır. Ayrıca, ilgili paydaşların kent ortamında ki doğal ve kültürel mirasın korunması ve yenilenmesine yönelik odaklanmayı da içermektedir. Kent ekoturizmin 4 temel amacı vardır (Urban Ecotourism Declaration (UED), 2006):

- Doğal ve kültürel mirası (doğal peyzaj, biyoçeşitlilik, yerel kültür) korumak ve yenilemek,

- Yerel yararları maksimize etmek, yerel halkın misafirlerin barınma ihtiyaçlarını karşılamasını ve rehberlik etmesini sağlamak,

- Çevresel konular, tarihi miras değerleri ve sürdürülebilirlik konularında kent insanının ve ziyaretçilerin farkındalıklarını artırmak ve bilinçlendirmek,

- Ekolojik ayak izlerini azaltmak şeklinde ifade edilmiştir.

Kent ekoturizmin 3 temel yararı bulunmaktadır (Wu, Wang ve Ho, 2010) (Şekil 1);

1. Sosyal Yararlar: Kentsel alanda ki yerel toplulukların içinde mekansal kavramlar, fiziksel özellikler ve toplu öğrenme faaliyetleri ile yerel deneyimler güçlenir. Böylece kent insanları ve ziyaretçiler gurur duyma ve sahip olma duygusunu geliştirir. Kentsel yaşamda farklı kültürlerin karışımı olarak ortaya çıkan kentsel farklı yerel topluluklarının birbirleriyle olan bağlantısını vurgulamak ve yerel kültür, gıda ve rekreasyon seçeneklerinin teşvik edilmesi sayesinde sağlıklı kentsel toplulukların oluşturulmasını sağlar.

2. Ekonomik yararlar: Yöreye ait malların ve hizmetlerin tüketimini teşvik ederek yerel ekonomiyi canlandırır. Yöresel ekonomide para dolaşımına yol açarak ekonomik fayda sağlar, böylece yerel esnekliği güçlendirir. 
3. Çevresel Yararlar: Aktif ulaşımı teşvik ederek (bisiklet sürmek, yürümek) kentsel yerleri keşfetmesi sağlanır ve seyahat seçeneklerini eve daha yakınlaştırarak enerji kullanımını azaltır. Kentsel ve doğal çevre arasındaki bağlantıları vurgulayarak, ilgili doğal ve kültürel mirasın korunması, canlandırılması ve eyleme dönüştürülmesi ile çevresel farkındalığı teşvik eder.

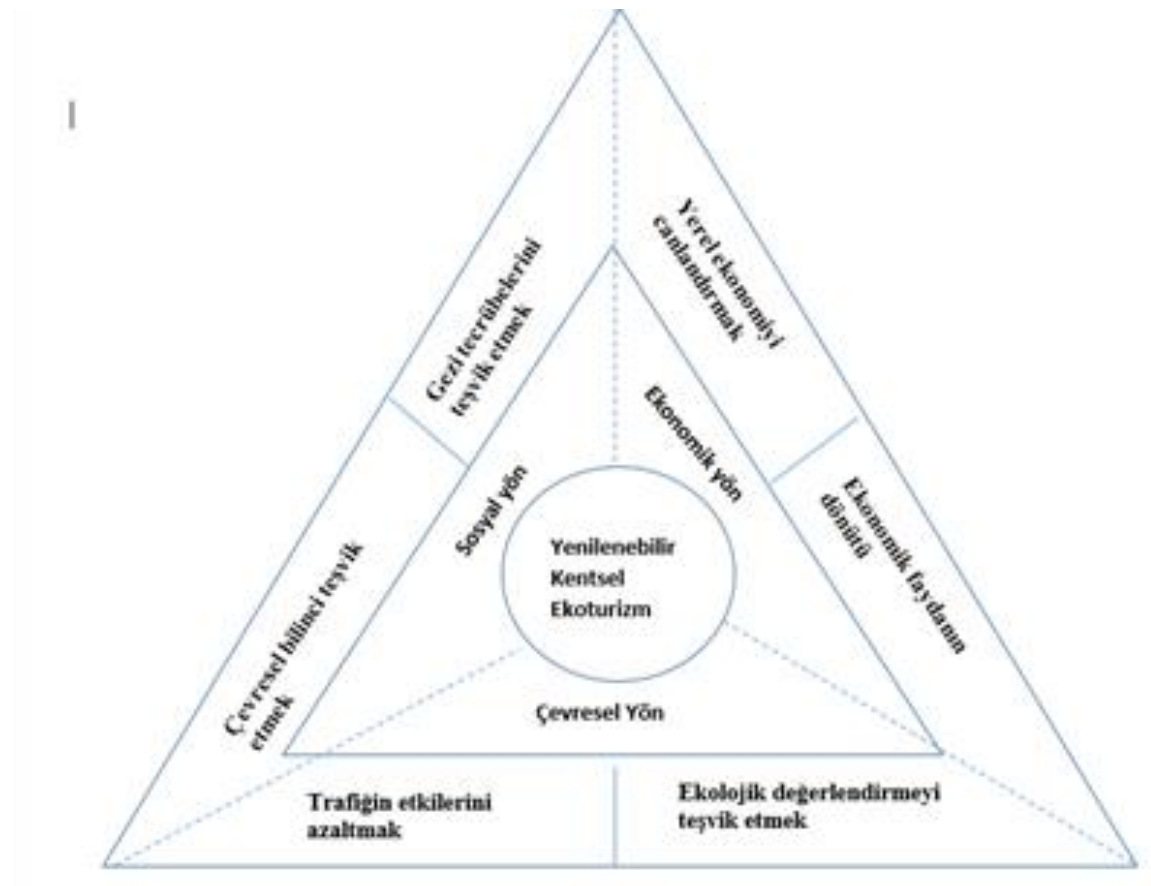

Şekil 1. Kentsel ekoturizmin temel yararları (Wu, Wang ve Ho, 2010)

\section{Materyal ve Yöntem}

Türkiye'nin önemli kentlerinden olan Isparta kenti, kırsal ve kentsel ögelerin buluştuğu/bütünleştiği bir peyzaja sahiptir. Isparta kenti, Akdeniz bölgesinde "Göller Bölgesi" olarak bilinen bölgede, merkezi bölge de dâhil olmak üzere 13 ilçeden oluşan orta büyüklükte bir kentin merkezidir. Isparta kenti Isparta Ovası'nda ortalama 1035 m yüksekliğinde ve yaklaşık 70 kilometrekare genişliğindedir. Isparta merkezinin topografyası güneyden kuzeye doğru düşük bir eğime sahiptir ve güney yüksek dağlarla çevrilidir (Gül ve Küçük, 2001).

Çalışma alanı, deniz seviyesinden 1,000m yüksekte, güneyden kuzeye doğru hafif meyilli bir alanda uzanmış olarak Isparta Çayı'nın iki tarafında kurulmuştur. Kentin kurulduğu sırtlar eğime uygun biçimde yamaçlardan ovaya doğru uzanmaktadır. İlk yerleşim yeri güneybatıdaki Hisar, güneydeki Sidre ve Kundaklı Ebe tepelerinden Minasın'a kadar uzanan eğimli alanlar ile Çelebi yeri denilen Paşa Çeşmeleri semti civarıdır (Böcüzade, 1983). Bazı kaynaklarda kentin ilk yerleşim yerinin, Belönü Çayı civarında Sidre Tepesi'nin eteklerinde bulunan Sülebey Mahallesi olduğu belirtilmektedir (Akdemir, 2008).

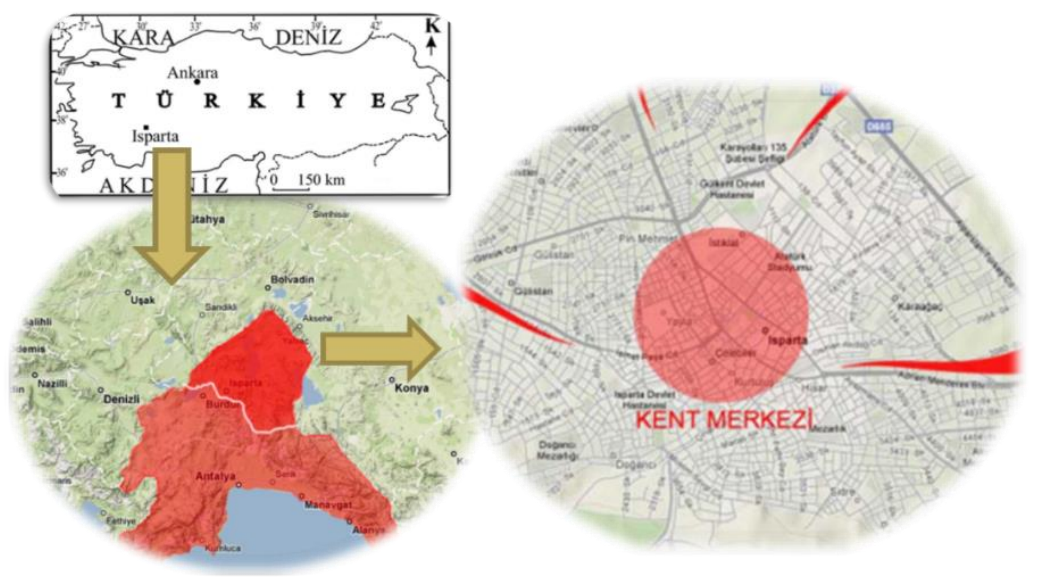

Şekil 2. Isparta kentinin konumu 
Çalışmanın aşamaları 4 başlıkta ele alınmıştır.

1. Kaynak Tarama Așaması: Konuyla ilgili yerli ve yabancı kaynaklar taranarak ve ilgili bilgiler güncellenmiştir. Kaynak arşiv dosyası oluşturulmuştur.

2. Envanter ve Sörvey Aşaması: Alana ilişkin literatür temelinde, yapılan gözlemler ve incelemeler sonucu ziyaretleri ile alana ilişkin doğal ve kültürel değerleri ekoturizm etkinlikleri raporlanmış/listelenmiş ve değerlendirilmiştir. Envanter çalışmasında doğal değerler (iklim, jeoloji, jeomorfoloji, biyolojik çeşitlilik, hidroloji, toprak yapısı, bitki örtüsü çeşitliliği ve eğim vb.) ve kültürel değerler (tarihi ve arkeolojik kalıntı ve eserler, tescilli anıtsal mimari yapılar, tescilli yaşlı ağaçlar, mermer ve taş ocakları, yöresel festivaller, folklor, yöresel ürün ve mimarisi, arazi kullanım desenleri vb.) belirlenerek alan envanteri çıkarılmıştır.

Çalışmada, Isparta kent halkının alan çalışmaları kapsamında elde edilen ekoturizm değerleri, bu konudaki beklenti ve taleplerini ortaya koymak için anket çalışması yapılmıştır. Anket 3 bölümden oluşmaktadır. Anketin 1. bölüm katılımcıların demografik özellikleri, ikinci bölüm katılımcıların ekoturizme ilişkin kavramsal bilgilerinin irdelenmesi, üçüncü bölümde ise ekoturizm eğilimleri ve talepleri ile ilgili sorular sorgulanmıştır. Anket Isparta' kentinde oturan halka, ekoturizm konusundaki uzmanlara (akademisyenlere, turizm uzmanlarına) ve temsilcilere (acente, şirket) uygulanmıştır. Ankete katılanlar rasgele yöntemle seçilmiştir. Anket formları, 2018-2019 tarihinde ve yüz yüze görüşme tekniği kullanılarak yaklaşık 20-30 dakika arasında doldurulmuştur. Anket çalışmaları için örnekleme sayısı için hedef kitledeki birey sayısı bilinmiyorsa $n=t^{2} p q / d^{2}$ formülü kullanılarak gerçekleştirilmiştir Baş (2006)'da belirtilen formül ve değerlendirme ile \%5 örnekleme hatası $(d=0.05)$ ile 409 kişiye uygulanmıştır.

Bu formülde; $n=t^{2} p q / d^{2}$ (Baş, 2006).

$\mathrm{n}$ : Örnekleme alınacak birey sayısı

p: Incelenen olayın görülüş sıklı̆ıı (gerçekleşme olasılığı)

q: İncelenen olayın görülmeyiş sıklığı (gerçekleşmeme olasılığı)

$\mathrm{t}$ : Belirli bir anlamlılık düzeyinde, $\mathrm{t}$ tablosuna göre bulunan teorik değer

d: Olayın görülüş sıkıı̆ına göre kabul edilen örnekleme hatasıdır.

Örnekleme sayısı için Isparta kent ölçeğinde \%5 örnekleme hatasını kabul edilmiştir ( $d=0.05)$ (Çizelge 1.).

3. Analiz ve Değerlendirme Aşaması: Anket çalışması sonucunda toplanan verilerin analizi için SPSS 22 programı kullanılmıştır. Katılımcıların ölçeklere verdikleri yanıtlara ilişkin faktör analizi ve güvenilirlik analizi uygulanmıştır. Faktör analizi ve güvenilirlik analizi sonucunda uygun değerler bulunduğundan dolayı ölçek puanları demografik değişkenlere göre analiz edilmiştir. Katılımcıların cinsiyetlerine göre ölçek puanları "Mann Whitney U" testi kullanılarak analiz edilmiştir. Yaş grupları, meslek grupları, eğitim durumları ve ikamet yerlerine göre ölçek puanlarının karşılaştırılmasında ise "Kruskal Wallis $\mathrm{H}^{\prime}$ testi kullanılmıştır. Katılımcıların demografik bilgilerinin yüzdelik dağılımlarının belirlenmesinde ve ekoturizmle ilgili çoktan seçmeli sorulara verdikleri yanıtların frekans ve yüzdelik dağıımlarının belirlenmesinde frekans analizi kullanılmıştır.

Çalışmada kent insanına yapılan anket verileri analizi sonucu elde edilen bulgular ile yapılan envanter ve sörvey çalışmalarından elde edilen veriler doğrultusunda GZFT analizi yapılmıştır. Bu bağlamda içsel faktör olarak Güçlü (Strengths) ve Zayıf (Weaknesses) yönleri belirlenmiş, dışsal faktör olarak kaynaklanan Fırsat (Opportunities) ve Tehditleri (Threats) saptanmıştır. Mevcut kentsel ekoturizm mevcut durum potansiyeli ortaya konulmuştur. GZFT analizi çalışması ile güçlü yönler daha fazla geliştirilmesi yönünde, zayıf yönleri ise güçlü hale dönüştürme yönünde eylemler öngörülmüştür.

Ayrıca eylemler uzmanlara ( $\mathrm{n}: 30$ ) yapılan 3'lü likert puanlama tekniğine "3 puan -Katılıyorum", 2 puan "Kararsızım", 1 puan -"Katılmıyorum" göre puanlandırılmak suretiyle GZFT öncelikleri belirlenmiştir. Bununla birlikte fırsatların güçlü yönleri ile ilişkilendirmek ve tehditleri ise fırsata dönüştürmek suretiyle bazı eylemler önerilmiştir.

4. Sonuç ve Öneriler: Çalışmada envanter ve sörvey çalışmaları ve anket bulguları kapsamında Isparta kent içi ve yakın çevresinin ekoturizm kaynak değerleri belirlenmiş ve GZFT yolu ile analiz edilerek mevcut durum tespit edilmiş ve öneriler getirilmiştir. 


\section{Bulgular ve Tartışma}

3.1. Isparta kent insanının kentsel ekoturizmi konusundaki talep ve eğilimlerine yönelik anket sonuçlarının analizi ve değerlendirmesi

\subsubsection{Ankete katılanların genel profili}

Ankete katılanların genel profili incelendiğinde, \%48'si kadın, \%52'ü erkeklerden oluşmaktadır. Yaş grupları açısından en fazla \%55'ini 18-35 yaş grubu ile \%21'ini 36-53 yaş grubu oluşturmaktadır. Katılımcıların büyük çoğunluğunu \%46'sı öğrenci ve $\% 21^{\prime}$ ini ise memur oluşturmaktadır. Katılımcıların \%34'ü lisans mezunu, \%24'ü yüksek lisans mezunudur. Katılımcıların \%80'i Isparta merkezde ikamet ederken, \%9'u Isparta'nın ilçelerinde, \%11'i diğer illerde ikamet etmektedir (Çizelge 1).

Çizelge 1. Ankete katılanların genel profili

\begin{tabular}{llc}
\hline Değişken & Alt değişken & Oran(\%) \\
\hline Cinsiyet & Erkek & 52 \\
& Kadın & 48 \\
\hline Yaş grubu & $18-35$ yaş & 55 \\
& $36-53$ yaş & 21 \\
& $53-70$ yaş & 20 \\
& 18 yaş altı & 4 \\
\hline Meslek & Öğrenci & 46 \\
& Memur & 21 \\
& Akademisyen & 18 \\
& Esnaf & 6 \\
& Ev hanımı & 5 \\
& İş̧i & 4 \\
\hline Eğitim durumu & Lisans & 34 \\
& Yüksek Lisans & 24 \\
& Ön lisans & 23 \\
& Lise & 15 \\
ikamet yeri & ilköğretim & 4 \\
\hline Toplam & Isparta merkez & 80 \\
\hline
\end{tabular}

Katılımcıların ekoturizmi tercih nedenleri incelendiğinde \%31'i nün doğayı keşfetme, \%13'ünün rekreasyonel etkinlik yapma isteği, \%13'ünün kendini keşfetme isteği, \%12'isinin insanlarla tanışma ve kültür gezisi, \%11'inin macera tutkusu, $\% 11$ 'inin sessiz ortam isteği, $\% 6^{\prime}$ sının bilimsel ve sosyal merak, \%3'ünün ise koruma amaçlı orijinal değerler görme nedenleri için ekoturizm yaptığı görülmektedir (Çizelge 2).

Çizelge 2. Katılımcıların ekoturizm aktivitelerini tercih etme nedenleri ve yüzdelik dağılımları

\begin{tabular}{|c|c|c|}
\hline Soru & Tercih nedenleri & Oran (\%) \\
\hline \multirow{8}{*}{$\begin{array}{l}\text { **Ekoturizm aktivitelerini } \\
\text { tercih etme nedenleriniz } \\
\text { nelerdir? }\end{array}$} & Doğayı keşfetme & 31 \\
\hline & Rekreasyonel etkinlik yapmak & 13 \\
\hline & Kendini keşfetmek ve dinlemek & 13 \\
\hline & İnsanlarla tanışma ve kültür gezisi & 12 \\
\hline & Macera tutkusu & 11 \\
\hline & Sessiz ortam isteği & 11 \\
\hline & Bilimsel ve sosyal merak & 6 \\
\hline & Koruma amaçlı orijinal değerler görmek & 3 \\
\hline Toplam & & 100,00 \\
\hline
\end{tabular}

**Birden fazla yanıt işaretlenebilir. Toplam cevap sayısı üzerinden yüzdelik dağılım incelenmiştir.

Araştırmaya katılanların \%73'ü Isparta ve çevresinde turizm faaliyetleri yaptığı görülmektedir (Çizelge 3). 
Çizelge 3. Katılımcıların 'Isparta ve çevresinde turizm yapıyor musunuz?' sorusuna verdikleri yanıtlar ve yüzde dağılımları

\begin{tabular}{lcc}
\multicolumn{1}{c}{ Soru } & Turizm etkinlikleri yapma durumu & Oran(\%) \\
\hline Isparta ve çevresinde turizm & Evet & 73 \\
etkinlikleri yapıyor musunuz? & Hayır & 27 \\
\hline Toplam & & 100,00 \\
\hline **Brden fazla yanıt isaretlenabilir. Toplam cevap sayısı üzerinden yüzdelik dağlım incelenmiştir.
\end{tabular}

**Birden fazla yanıt işaretlenebilir. Toplam cevap sayısı üzerinden yüzdelik dağılım incelenmiştir.

Araştırmaya katılanların \%59'unun ekoturizm faaliyetleri yaptığı görülmektedir (Çizelge 4).

Çizelge 4. Katılımcıların 'Isparta ve çevresinde ekoturizm yapıyor musunuz?' sorusuna verdikleri yanıtlar ve yüzde dağılımları

\begin{tabular}{lcc}
\multicolumn{1}{c}{ Soru } & Ekoturizm etkinlikleri yapma durumu & Oran(\%) \\
\hline $\begin{array}{l}\text { Isparta ve çevresinde ekoturizm } \\
\text { etkinlikleri yapıyor musunuz? }\end{array}$ & Evet & 59 \\
\hline Toplam & Hayır & 41 \\
\hline
\end{tabular}

Katılımcıların Isparta ve çevresinde ekoturizm tercih etmelerinde en fazla etkili olan faktörler incelendiğinde, $\% 18^{\prime} \mathrm{i}$ tur acentesinin yönlendirmesi, $\% 16$ 'sı turist veya tanıdık tavsiyesi, $\% 16$ 'sı internet aracılı̆ı, \%11'i yazılı ve görsel medya ile tanıtım, \%14'ü ulaşım mesafesi, \%13'ü ulaşım araçlarının varlığı, \%11'i daha önce gitmiş olmaları, \%1'i ise diğer faktörlerin en etkili faktörler olduğunu ifade etmektedir (Çizelge 5).

Çizelge 5. Katılımcıların Isparta ve çevresinde turizm ve/veya ekoturizm faaliyetlerini tercih etmelerine en fazla etkili olan faktörler ve yüzde dağılımları

\begin{tabular}{llc}
\hline \multicolumn{1}{c}{ Soru } & \multicolumn{1}{c}{ Tercih edilme nedenleri } & Oran(\%) \\
\hline & Tur acentesinin yönlendirilmesi & 18 \\
& Turist veya tanıdık tavsiyesi & 16 \\
& İnternet aracılığıyla & 16 \\
Isparta ve çevresinde turizm ve/veya & Yazılı ve görsel medya ile tanıtım & 11 \\
ekoturizm etkinliklerinin tercih & Ulaşım mesafesi & 14 \\
edilmesinde etkili olan faktörler nelerdir? & Ulaşım araçlarının varlığı & 13 \\
& Daha önce gitmiş olmak & 11 \\
& & 1
\end{tabular}

\begin{tabular}{cc}
\hline Toplam & 100,00 \\
\hline & $* *$ Birden fazla yanıt işaretlenebilir. Toplam cevap sayısı üzerinden yüzdelik dağılım incelenmiştir.
\end{tabular}

Kentte ekoturizmin sağlayacağı katkılar hakkındaki görüşler incelendiğinde, katılımcıların \%19'u mutlu olma, \%18'i doğadaki canlılarla yakın iletişim, \%14'ü yaşam sevinci, \%14'ü insanlarla sağıklı iletişim kurma, \%12'si doğayı anlama, \%10'u farkındalık ve bilinçlenme $\% 9$ 'u yenilenme $\% 4$ 'ü sorumluluk hissi kazandırma ile ilgili katkısı olacağını ifade etmektedir (Çizelge 6). 
Çizelge 6. Katılımcılara göre kentte ekoturizm faaliyetlerinin size sağlayacağı katkılar ve yüzde dağılımları

\begin{tabular}{lll}
\hline \multirow{2}{*}{ Soru } & \multicolumn{1}{c}{ Ekoturizm etkinliklerinin katkıları } & Oran(\%) \\
& Mutlu olma & 19 \\
& Doğadaki canlılarla yakın iletişim & 18 \\
& Yaşam sevinci & 14 \\
Kentte ekoturizm etkinliklerinin size & İnsanlarla sağlıklı iletişim kurma & 14 \\
sağlayacağı katkılar nelerdir? & Doğayı anlama & 12 \\
& Farkındalık ve bilinçlenme & 10 \\
& Yenilenme & 9 \\
\hline \multirow{2}{*}{ Toplam } & Sorumluluk hissi kazandırma & 4 \\
\hline
\end{tabular}

\subsubsection{Katılımcıların ekoturizme ilişkin talep ve beklentileri}

Katılımcıların ekoturizm talepleri incelendiğinde, katılımcıların Isparta'da talep ettikleri ekoturizm faaliyetlerinin başında doğa yürüyüşü $(\% 28,6)$, dağ bisikleti gezme $(\% 9,4)$ geliyorken, en az talep ettikleri ekoturizm faaliyetlerinin erozyon önleme $(\% 1,1)$ ve diğer $(\% 1,6)$ faaliyetleri olduğu görülmektedir (Çizelge 7).

Çizelge 7. Katılımcıların Isparta'da talep ettiği ekoturizm faaliyetleri ve yüzde dağılımları

\begin{tabular}{llc}
\hline \multirow{2}{*}{ Soru } & \multicolumn{1}{c}{ Talep edilen ekoturizm etkinlikleri } & Oran(\%) \\
& Doğa yürüyüşü & 29 \\
& Dağ bisikleti gezme & 9 \\
& Fotoğraf çekmek & 9 \\
& Bitki gözleme & 7 \\
& Tarihi ve antik yerlere geziler & 7 \\
& Gül toplama ve üretim faaliyetleri & 6 \\
& Orienteering (Hedef bulma) & 5 \\
& Kültürel yapı ve objelerin gezilmesi & 5 \\
& Bitlendirme faaliyetleri & 5 \\
& Yaban hayatını gözleme & 4 \\
& Sokak hayvanlarının korunması ve bakımı & 4 \\
& Yabani ot temizliği & 3 \\
& Mahalle ve çocuk oyun alanları yapma ve & 2 \\
& organizasyon & 2 \\
& Hobi bahçelerinde sebze yetiştirme & 2 \\
& Diğer \\
& Erozyon önleme çalışmaları & 1 \\
\hline \multirow{2}{*}{ Toplam } & & 100,00 \\
\hline
\end{tabular}

**Birden fazla yanıt işaretlenebilir. Toplam cevap sayısı üzerinden yüzdelik dağılım incelenmiştir.

Katılımcıların \%21'i kent parkların, \%18'i kentsel açık ve yeşil alanların, \%13'ü çay boyu yeşil kuşağın tercih edilebilecek alanlar olduğunu ifade etmektedir (Çizelge 8). 
Çizelge 8. Katılımcılara göre Isparta ve çevresinde ekoturizm faaliyetleri için tercih edilebilen alanlar ve yüzde dağılımları

\begin{tabular}{|c|c|c|}
\hline Soru & $\begin{array}{l}\text { Ekoturizm etkinlikleri için tercih edilen } \\
\text { alanlar }\end{array}$ & Oran(\%) \\
\hline \multirow{14}{*}{$\begin{array}{l}{ }^{* *} \text { Isparta ve çevresinde ekoturizm } \\
\text { etkinlikleri için hangi alanlar tercih } \\
\text { edilebilir? }\end{array}$} & Kent parkları (Ayazmana, Gökçay) & 21 \\
\hline & Kentsel açık ve yeşil alanlar & 18 \\
\hline & Çay boyu yeşil kuşak & 13 \\
\hline & Kent ormanları & 9 \\
\hline & Gül bahçeleri & 8 \\
\hline & Mahalle parkı & 6 \\
\hline & Müzeler & 6 \\
\hline & Tarım alanları & 4 \\
\hline & Milas mesireliği & 3 \\
\hline & Elma ve kiraz bahçeleri & 3 \\
\hline & Hobi bahçeleri & 3 \\
\hline & SDÜ botanik bahçesi & 3 \\
\hline & SDÜ yerleşkesi & 2 \\
\hline & Diğer & 1 \\
\hline Toplam & & 100,00 \\
\hline
\end{tabular}

**Birden fazla yanıt işaretlenebilir. Toplam cevap sayısı üzerinden yüzdelik dağılım incelenmiştir.

Araştırmaya katılanların \%33'ü Isparta ve çevresinde yer alan ekoturizm alanlarına yaya olarak giderken, \%27'si özel araçla, \%22'si toplu taşımayla, , \%10'u bisikletle, \%7'si motosikletle ve \%1'i diğer şekillerde gitmektedir (Çizelge 9).

Çizelge 3.9. Katılımcıların Isparta ve çevresinde yer alan kentsel ekoturizm alanlarına gidiş şekli ve yüzde dağılımları

\begin{tabular}{|c|c|c|}
\hline Soru & $\begin{array}{l}\text { Ekoturizm etkinlik alanlarına ulaşma } \\
\text { şekli }\end{array}$ & Oran(\%) \\
\hline \multirow{6}{*}{$\begin{array}{l}\text { **Isparta ve yakın çevresinde yer alan kentsel } \\
\text { ekoturizm alanlarına nasıl gidersiniz? }\end{array}$} & Yaya olarak & 33 \\
\hline & Özel araçla & 27 \\
\hline & Toplu taşımayla & 22 \\
\hline & Bisikletle & 10 \\
\hline & Motosikletle & 7 \\
\hline & Diğer & 1 \\
\hline Toplam & & 100,00 \\
\hline
\end{tabular}

**Birden fazla yanıt işaretlenebilir. Toplam cevap sayısı üzerinden yüzdelik dağılım incelenmiştir.

Katılımcıların \%32'si haftada bir kez giderken, \%28'si ayda bir kez, \%18'si ekoturizm alanlarına haftada birden fazla, \%14'ü yılda bir kez, \%8'i ise çok ender olarak gitmektedir (Çizelge 10).

Çizelge 10. Katılımcıların kentsel ekoturizm faaliyetlerini gerçekleştirme sıklığı ve yüzde dağılımları

\begin{tabular}{lll}
\hline Soru & Ekoturizm etkinliklerini & Oran(\%) \\
\hline & gerçekleştirme sıklığı & 32 \\
& Haftada bir & 28 \\
Kentsel ekoturizm etkinliklerini hangi sıklıkla & Ayda bir & 18 \\
gerçekleştirirsiniz? & Haftada birden fazla & 14 \\
& Çok ender & 8 \\
\hline
\end{tabular}

$\begin{array}{ll}\text { Toplam } & 100,00\end{array}$

**Birden fazla yanıt işaretlenebilir. Toplam cevap sayısı üzerinden yüzdelik dağılım incelenmiştir.

Katılımcıların kentsel ekoturizm alanlarına en fazla mayıs (\%23), nisan (\%21) ve haziran (\%13) aylarında gittikleri görülmektedir (Çizelge 11). 
Çizelge 11. Katılımcıların kentsel ekoturizm alanlarına gittiği aylar ve yüzde dağılımları

\begin{tabular}{|c|c|c|}
\hline Soru & Ekoturizm alanlarına gitme zamanı & $\%$ \\
\hline \multirow{9}{*}{$\begin{array}{l}\text { **Kentsel ekoturizm alanlarına hangi aylarda } \\
\text { gidersiniz? }\end{array}$} & Ocak & 2 \\
\hline & Şubat & 2 \\
\hline & Mart & 5 \\
\hline & Nisan & 21 \\
\hline & Mayıs & 23 \\
\hline & Haziran & 13 \\
\hline & Temmuz & 15 \\
\hline & Ağustos & 10 \\
\hline & Eylül & 9 \\
\hline \multicolumn{2}{|l|}{ Toplam } & 100,00 \\
\hline \multicolumn{3}{|c|}{$\begin{array}{l}\text { **Birden fazla yanıt işaretlenebilir. Toplam cevap sayısı üzerinden yüzdelik dağılım incelenmiştir. } \\
\text { Katılımcıların kentsel ekoturizm alanlarına gün olarak ise en fazla Cumartesi (\%37), Pazar (\%33) ve } \\
\text { Cuma (\%18) günlerinde gittikleri görülmektedir (Çizelge 12). }\end{array}$} \\
\hline \multicolumn{3}{|c|}{ Çizelge 12. Katılımcıların kentsel ekoturizm alanlarını tercih ettiği günler ve yüzde dağılımları } \\
\hline Soru & $\begin{array}{l}\text { Ekoturizm alanlarına gidilmesi } \\
\text { tercih edilen günler }\end{array}$ & Oran(\%) \\
\hline \multirow{7}{*}{$\begin{array}{l}\text { **Ekoturizm alanlarını tercih edeceğiniz } \\
\text { günler hangileridir? }\end{array}$} & Cumartesi & 37 \\
\hline & Pazar & 33 \\
\hline & Cuma & 18 \\
\hline & Perşembe & 5 \\
\hline & Çarşamba & 4 \\
\hline & Pazartesi & 2 \\
\hline & Salı & 1 \\
\hline \multicolumn{2}{|l|}{ Toplam } & 100,00 \\
\hline
\end{tabular}

**Birden fazla yanıt işaretlenebilir. Toplam cevap sayısı üzerinden yüzdelik dağıım incelenmiştir.

Araştırmaya katılanların \%11'i ekoturizm alanlarına saat 05:00-08:00 arasında gittiğini ifade ederken, \%32'si 08:00-12:00 arasında gittiğini, \%26'sı 12:00-16:00 arasında gittiğini, \%26'si 16:00-20:00 arasında gittiğini, \%5’i 20:00-24:00 arasında gittiğini ifade etmektedir (Çizelge 13).

Çizelge 13. Katılımcıların kentsel ekoturizm etkinlikleri için tercih edilen saatler ve yüzde dağılımları

\begin{tabular}{clc} 
Soru & $\begin{array}{c}\text { Ekoturizm etkinlikleri için tercih } \\
\text { edilen saatler }\end{array}$ & Oran(\%) \\
\hline & $08: 00-12: 00$ arası & 32 \\
Ekoturizm etkinliklerini genellikle günün hangi & $12: 00-16: 00$ arası & 26 \\
saatlerinde yaparsınız? & $16: 00-20: 00$ arası & 26 \\
& $20: 00-08: 00$ arası & 11 \\
\hline Toplam & & 5 \\
\hline
\end{tabular}

**Birden fazla yanıt işaretlenebilir. Toplam cevap sayısı üzerinden yüzdelik dağılım incelenmiştir.

Katılımcıların \%31'i ekoturizm etkinliklerinde 2-4 saat zaman geçiriyorken, \%34'ü 4-6 saat zaman geçirmekte ve \%20'si ise 6-8 saat zaman geçirmektedir (Çizelge 14). 
Çizelge 14. Katılımcıların kentsel ekoturizm etkinlikleri için harcanan süre ve yüzde dağılımları

\begin{tabular}{ccc}
\hline Soru & Yanit & Oran(\%) \\
\hline & $4-6$ saat & 34 \\
Ekoturizm etkinliklerini ne kadar sürede yapmak & $2-4$ saat & 31 \\
istersiniz? & $6-8$ saat & 20 \\
& $8-10$ saat & 6 \\
& $0-2$ saat & 6 \\
\hline Toplam & 10 saatten fazla & 100,00
\end{tabular}

**Birden fazla yanıt işaretlenebilir. Toplam cevap sayısı üzerinden yüzdelik dağılım incelenmiştir.

Katılımcıların \%24'ü ekoturizm faaliyetleri için günlük harcama yapmazken, \%17'si 30TL ve altında harcama yapmakta, \%24'ü 30-100TL harcama yapmakta, \%21'i 100-150TL harcama yapmakta, \%12'si 150-250TL harcama yapmakta ve \%2'si 250TL ve üzerinde harcama yapmaktadır (Çizelge 15).

Çizelge 15. Katılımcıların kentsel ekoturizm etkinlikleri için günlük kişi başı ortalama harcanan miktar ve yüzde dağılımları

\begin{tabular}{ccc}
\hline \multirow{2}{*}{ Soru } & $\begin{array}{c}\text { Ekoturizm etkinlikleri için günlük } \\
\text { harcama miktarı (TL) }\end{array}$ & $\%$ \\
\hline & Harcama yapmıyor & 24 \\
Ekoturizm etkinlikleri için günlük kişi başı & $30-100 \mathrm{TL}$ & 24 \\
ortalama ne kadar harcama yapabilirsiniz? & $100-150 \mathrm{TL}$ & 21 \\
& $30 \mathrm{TL}$ altı & 17 \\
\hline Toplam & $150-250 \mathrm{TL}$ & 12 \\
\hline
\end{tabular}

**Birden fazla yanıt işaretlenebilir. Toplam cevap sayısı üzerinden yüzdelik dağılım incelenmiştir.

Çizelge incelendiğinde, katılımcıların \%69'unun ısparta şehir merkezi ve yakın çevresinde kentsel ekoturizm etkinlikleri rotasının olmasını istediği belirtilmiştir (Çizelge 16).

Çizelge 16. Katılımcıların Isparta şehir merkezi ve yakın çevresinde kentsel ekoturizm etkinlik rotasının olmasını isteyenlerin yüzde dağılımları

\begin{tabular}{lcc}
\multicolumn{1}{c}{ Soru } & $\begin{array}{c}\text { Ekoturizm etkinlikleri rotasının } \\
\text { olmasını isteyenler }\end{array}$ & $\%$ \\
\hline Isparta şehir merkezi ve yakın çevresinde & Evet & 69 \\
kentsel ekoturizm etkinlikleri rotasının & Fikrim yok & 22 \\
olmasını ister misiniz? & Hayır & 9 \\
\hline
\end{tabular}

Toplam

100,00

Katılımcıların \%14'ünün rotanın 5 km'den az olmasını istediği, \%35'inin 5-10 km olmasını istediği, $\% 27$ 'sinin 10-15 km olmasını istediği, \%23'ünün 15-30 km olmasını istediği, \%1'sinin ise $30 \mathrm{~km}$ üzerinde olmasını istediği görülmektedir (Çizelge 17).

Çizelge 17. Katılımcılara göre Isparta şehir merkezi ve yakın çevresinde kentsel ekoturizm etkinlikleri rotasının mesafesi ve yüzde dağılımları

\begin{tabular}{|c|c|c|}
\hline Soru & Rota mesafesi & $\%$ \\
\hline & $5-10 \mathrm{~km}$ & 35 \\
\hline Isparta şehir merkezi ve yakın çevresinde kentsel ekoturizm & $10-15 \mathrm{~km}$ & 27 \\
\hline etkinlikleri rotasının olmasını istiyorsanız rotaların mesafesi ne & $15-30 \mathrm{~km}$ & 23 \\
\hline olmalıdır? & $<5 \mathrm{~km}$ & 14 \\
\hline & $30 \mathrm{~km}<$ & 1 \\
\hline Toplam & & 100,00 \\
\hline
\end{tabular}




\subsubsection{Ankete katılanların kent ekoturizme yönelik cinsiyete, yaşa, mesleğe, eğitim durumlarına ve ikamet yerine göre karşılaştırılmaları}

Çizelgeler incelendiğinde, katılımcıların ekoturizm kavramı algı düzeylerinin ve bilgi düzeylerinin yüksek olduğu, ekoturizm faaliyetleri bilgi düzeylerinin ise orta düzeyde olduğu görülmektedir (Çizelge 18).

Çizelge 18. Katılımcıların ekoturizm kavramı algı ölçeği, ekoturizm faaliyet bilgi ölçeği ve ekoturizm fayda bilgi ölçeği puanlarına ilişkin tanımlayıcı istatistikler

\begin{tabular}{cccc}
\hline Ölçek & $\mathbf{N}$ & $\mathbf{X}$ & Ss \\
\hline Kavram algı & 409 & 4,24 &, 735 \\
Faaliyet bilgi & 409 & 4,16 &, 582 \\
Fayda bilgi & 409 & 4,25 &, 708 \\
\hline
\end{tabular}

( $\mathrm{N}=$ Kişi sayısı, $\mathrm{X}=$ Aritmetik ortalama, Ss= Standart Sapma)

Çizelge incelendiğinde, kadınların ekoturizm kavramı algı düzeyinin erkeklerden anlamlı düzeyde daha yüksek olduğu $(U=18121,0 ; p<0,05)$, ekoturizm faaliyetleri bilgi düzeyi ve ekoturizm faaliyetleri fayda bilgi düzeyinin ise katılımcıların cinsiyetleri bakımından anlamlı düzeyde farklılaşmadığı görülmektedir (Çizelge 19).

Çizelge 19. Katılımcıların ekoturizm kavramı algı ölçeği, ekoturizm faaliyet bilgi ölçeği ve ekoturizm fayda bilgi ölçeği puanlarının cinsiyete göre karşılaştırılması

\begin{tabular}{lllllllll}
\hline Ölçek & Cinsiyet & $\mathbf{N}$ & $\mathbf{X}$ & Ss & Sıra ort. & Sıra top. & U & $\mathbf{p}$ \\
\hline Kavram & Kadın & 195 & 4,33 & 0,65 & 219,07 & 42719,0 & \multirow{2}{*}{$, 0121,0$} &, 021 \\
algı & Erkek & 214 & 4,16 & 0,80 & 192,18 & 41126,0 & & \\
Faaliyet & Kadın & 195 & 4,21 & 0,53 & 213,59 & 41650,5 & 19189,5 &, 160 \\
bilgi & Erkek & 214 & 4,12 & 0,62 & 197,17 & 42194,5 & &, 138 \\
Fayda & Kadın & 195 & 4,29 & 0,68 & 214,02 & 41734,5 & 19105,5 &, \\
bilgi & Erkek & 214 & 4,21 & 0,73 & 196,78 & 42110,5 & &
\end{tabular}

( $N=$ Kişi sayısı, $\mathrm{X}=$ Aritmetik ortalama, $\mathrm{Ss}=$ Standart Sapma)

( $U=$ Mann Whitney $U$ test değeri, $p=$ percent kelimesinin kısaltması)

Çizelge incelendiğinde, katılımcıların yaş grupları bakımından ekoturizm kavramı algı düzeylerinin $\left(x^{2}=44,0 ; p<0,05\right)$, ekoturizm faaliyetleri bilgi düzeylerinin $\left(x^{2}=34,3 ; p<0,05\right)$ ve ekoturizm fayda bilgi düzeylerinin $(x 2=16,3 ; p<0,05)$ anlamlı olarak farklılaştığı görülmektedir. Anlamlı fark olan ekoturizm kavramı algı, faaliyet bilgi ve fayda bilgi düzeylerinde, 18 yaş ve altı, 36-53 yaş ve 53-70 yaş grubundaki katılımcıların ekoturizm kavramı algı, faaliyet bilgi ve fayda bilgi düzeylerinin 18-35 yaş grubundaki katılımcılardan anlamlı düzeyde daha yüksek olduğu görülmektedir (Çizelge 20).

Çizelge 20. Katılımcıların ekoturizm kavramı algı ölçeği, ekoturizm faaliyet bilgi ölçeği ve ekoturizm fayda bilgi ölçeği puanlarının yaş gruplarına göre karşılaştırılması

\begin{tabular}{lllllllll} 
Ölçek & Yaş grubu & $\mathbf{N}$ & $\mathbf{X}$ & Ss & Sıra top. & $\mathbf{x}^{\mathbf{2}}$ & $\mathbf{p}$ & $\begin{array}{c}\text { Gruplar } \\
\text { fark }\end{array}$ \\
\hline \multirow{2}{*}{ Kavram } & 18 yaş altı & 18 & 4,39 & 0,32 & 204,03 & & & \\
algı & $18-35$ yaş & 223 & 4,03 & 0,83 & 171,00 & 44,0 &, 000 & $1>2,2<3,2<4$ \\
& $36-53$ yaş & 86 & 4,54 & 0,49 & 257,35 & & & \\
& $53-70$ yaş & 82 & 4,46 & 0,55 & 242,77 & & & \\
Faaliyet & 18 yaş altı & 18 & 4,36 & 0,19 & 234,19 & & & $1>2,2<3,2<4$ \\
bilgi & $18-35$ yaş & 223 & 4,01 & 0,66 & 173,87 & 34,4 &, 000 & \\
& $36-53$ yaş & 86 & 4,37 & 0,37 & 247,38 & & & \\
Fayda & 53-70 yaş & 82 & 4,31 & 0,46 & 238,80 & & & $1>2,2<3,2<4$ \\
bilgi & 18 yaş altı & 18 & 4,38 & 0,24 & 194,64 & & & \\
& $18-35$ yaş & 223 & 4,11 & 0,83 & 185,70 & 16,3 &, 001 & \\
\hline
\end{tabular}

( $\mathrm{N}=$ Kişi sayısı, $\mathrm{X}=$ Aritmetik ortalama, $\mathrm{Ss}=$ Standart Sapma)

( $x^{2}=$ Kruskal Wallis $\mathrm{H}$ testi Ki Kare değeri , $\mathrm{p}=$ percent kelimesinin kısaltması)

Çizelge incelendiğinde, katılımcıların meslek grubu bakımından ekoturizm kavramı algı düzeylerinin $\left(x^{2}=86,68 ; p<0,05\right)$, ekoturizm faaliyetleri bilgi düzeylerinin $\left(x^{2}=67,49 ; p<0,05\right)$ ve ekoturizm fayda bilgi 
düzeylerinin $(x 2=44,93 ; p<0,05)$ anlamlı olarak farklılaştığı görülmektedir. Anlamlı fark olan ekoturizm kavramı algısında memur, öğrenci, ev hanımı ve diğer meslek grubundaki katılımcıların algısının işçi olan katılımcılardan anlamlı düzeyde daha yüksek olduğu, ayrıca diğer meslek grubunda bulunan katılımcıların algısının öğrenci ve esnaf olan katılımcılardan anlamlı düzeyde daha yüksek olduğu görülmektedir $(p<0,05)$. Anlamlı fark olan ekoturizm faaliyet bilgisinde, memur, öğrenci, ev hanımı ve diğer meslek gruplarındaki katılımcıların bilgi faaliyet bilgi düzeyinin işçi olan ve esnaf olan katıımcılardan anlamlı düzeyde daha yüksek olduğu, diğer meslek gruplarındaki katılımcıların faaliyet bilgi düzeyinin memur olan ve ev hanımı olan katılımcılardan anlamlı düzeyde daha yüksek olduğu görülmektedir $(p<0,05)$. Anlamlı fark olan ekoturizm fayda bilgi düzeyinde, memur ve diğer meslek gruplarındaki katılımcıların ekoturizm fayda bilgi düzeyinin öğrenci ve esnaf olan katılımcılardan anlamlı düzeyde daha yüksek olduğu görülmektedir (Çizelge 21).

Çizelge 21. Katılımcıların ekoturizm kavramı algı ölçeği, ekoturizm faaliyet bilgi ölçeği ve ekoturizm fayda bilgi ölçeği puanlarının meslek gruplarına göre karşılaştırılması

\begin{tabular}{|c|c|c|c|c|c|c|c|c|}
\hline Ölçek & Meslek grubu & N & $x$ & Ss & Sira top. & $x^{2}$ & $p$ & $\begin{array}{l}\text { Gruplar arası } \\
\text { fark }\end{array}$ \\
\hline \multirow{6}{*}{$\begin{array}{l}\text { Kavram } \\
\text { algı }\end{array}$} & Memur & 69 & 4,28 & 0,69 & 212,13 & \multirow{6}{*}{86,68} & \multirow{6}{*}{, 000 } & \multirow{6}{*}{$\begin{array}{l}1>3,1<6,2>3, \\
3<5,3<6,4<6\end{array}$} \\
\hline & İşçi & 18 & 4,42 & 0,64 & 243,58 & & & \\
\hline & Öğrenci & 188 & 3,95 & 0,83 & 153,98 & & & \\
\hline & Esnaf & 16 & 4,29 & 0,44 & 178,00 & & & \\
\hline & Ev hanımı & 11 & 4,60 & 0,33 & 253,59 & & & \\
\hline & Diğer & 107 & 4,64 & 0,34 & 282,60 & & & \\
\hline \multirow{6}{*}{$\begin{array}{l}\text { Faaliyet } \\
\text { bilgi }\end{array}$} & Memur & 69 & 4,20 & 0,54 & 215,83 & \multirow{6}{*}{67,49} & \multirow{6}{*}{,000 } & \multirow{6}{*}{ 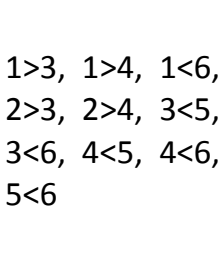 } \\
\hline & İşçi & 18 & 4,18 & 0,72 & 236,31 & & & \\
\hline & Öğrenci & 188 & 3,99 & 0,64 & 163,45 & & & \\
\hline & Esnaf & 16 & 4,03 & 0,32 & 138,47 & & & \\
\hline & Ev hanımı & 11 & 4,32 & 0,13 & 215,73 & & & \\
\hline & Diğer & 107 & 4,44 & 0,39 & 274,60 & & & \\
\hline \multirow{6}{*}{ Fayda bilgi } & Memur & 69 & 4,36 & 0,57 & 226,71 & \multirow{6}{*}{44,93} & \multirow{6}{*}{, 000 } & \multirow{6}{*}{$\begin{array}{l}1>3,1>4,3<6, \\
4<6\end{array}$} \\
\hline & İşçi & 18 & 4,19 & 0,89 & 209,56 & & & \\
\hline & Öğrenci & 188 & 4,05 & 0,82 & 169,02 & & & \\
\hline & Esnaf & 16 & 4,13 & 0,55 & 159,56 & & & \\
\hline & Ev hanımı & 11 & 4,45 & 0,29 & 222,45 & & & \\
\hline & Diğer & 107 & 4,54 & 0,42 & 258,45 & & & \\
\hline
\end{tabular}

( $\mathrm{N}=$ Kişi sayısı, $\mathrm{X}=$ Aritmetik ortalama, $\mathrm{Ss}=$ Standart Sapma)

( $x^{2}=$ Kruskal Wallis $\mathrm{H}$ testi Ki Kare değeri, $\mathrm{p}=$ percent kelimesinin kısaltması)

Çizelge incelendiğinde, katılımcıların eğitim durumu bakımından ekoturizm kavramı algı düzeylerinin $(x 2=86,8 ; p<0,05)$, ekoturizm faaliyetleri bilgi düzeylerinin $(x 2=71,8 ; p<0,05)$ ve ekoturizm fayda bilgi düzeylerinin $(\times 2=52,3 ; p<0,05)$ anlamlı olarak farklılaştığı görülmektedir. Anlamlı farklıık bulunan ekoturizm kavramı algı ve faaliyet bilgi düzeylerinde, ilköğretim, lise, ön lisans ve yüksek lisans mezunu katılımcıların algı ve faaliyet bilgi düzeyinin lisans mezunu olan katılımcılardan anlamlı düzeyde daha yüksek olduğu, ayrıca yüksek lisans mezunu olan katılımcıların algı ve faaliyet bilgi düzeyinin ilköğretim mezunu, lise mezunu ve ön lisans mezunu olan katılımcılardan anlamlı düzeyde daha yüksek olduğu görülmektedir $(p<0,05)$.

Anlamlı farklılık bulunan ekoturizm fayda bilgi düzeyinde, ilköğretim, lise, ön lisans ve yüksek lisans mezunu katılımcıların fayda bilgi düzeyinin lisans mezunu olan katılımcılardan anlamlı düzeyde daha yüksek olduğu, ayrıca yüksek lisans mezunu ve ön lisans mezunu olan katılımcıların fayda bilgi düzeyinin lise mezunu olan katılımcılardan anlamlı düzeyde daha yüksek olduğu görülmektedir $(p<0,05)$ (Çizelge 22). 
Çizelge 22. Katılımcıların ekoturizm kavramı algı ölçeği, ekoturizm faaliyet bilgi ölçeği ve ekoturizm fayda bilgi ölçeği puanlarının eğitim durumlarına göre karşılaştırılması

\begin{tabular}{|c|c|c|c|c|c|c|c|c|}
\hline Ölçek & Eğitim durumu & $\mathbf{N}$ & $x$ & Ss & Sira top. & $x^{2}$ & $\mathbf{p}$ & $\begin{array}{c}\text { Gruplar arası } \\
\text { fark }\end{array}$ \\
\hline \multirow{5}{*}{$\begin{array}{l}\text { Kavram } \\
\text { algı }\end{array}$} & illköğretim & 19 & 4,43 & 0,32 & 213,95 & \multirow{5}{*}{86,8} & \multirow{5}{*}{,000 } & \multirow{5}{*}{$\begin{array}{c}1>4,1<5,2>4 \\
2<5,3>4,3<5 \\
4<5\end{array}$} \\
\hline & Lise & 60 & 4,27 & 0,83 & 215,73 & & & \\
\hline & Ön lisans & 95 & 4,27 & 0,77 & 214,16 & & & \\
\hline & Lisans & 137 & 3,89 & 0,77 & 138,04 & & & \\
\hline & Yüksek Lisans & 98 & 4,65 & 0,30 & 281,42 & & & \\
\hline \multirow{5}{*}{$\begin{array}{l}\text { Faaliyet } \\
\text { bilgi }\end{array}$} & ilköğretim & 19 & 4,29 & 0,33 & 206,55 & \multirow{5}{*}{71,8} & \multirow{5}{*}{,000 } & \multirow{5}{*}{$\begin{array}{c}1>4,1<5,2>4 \\
2<5,3>4,3<5 \\
4<5\end{array}$} \\
\hline & Lise & 60 & 4,14 & 0,52 & 196,22 & & & \\
\hline & Ön lisans & 95 & 4,21 & 0,52 & 213,88 & & & \\
\hline & Lisans & 137 & 3,90 & 0,69 & 148,68 & & & \\
\hline & Yüksek Lisans & 98 & 4,47 & 0,34 & 280,20 & & & \\
\hline \multirow{5}{*}{ Fayda bilgi } & ilköğretim & 19 & 4,46 & 0,29 & 230,18 & \multirow{5}{*}{52,3} & \multirow{5}{*}{,000 } & \multirow{5}{*}{$\begin{array}{l}1>4,2<3,2>4, \\
2<5,3>4,4<5\end{array}$} \\
\hline & Lise & 60 & 4,12 & 0,82 & 184,33 & & & \\
\hline & Ön lisans & 95 & 4,31 & 0,76 & 230,27 & & & \\
\hline & Lisans & 137 & 4,02 & 0,76 & 154,92 & & & \\
\hline & Yüksek Lisans & 98 & 4,55 & 0,35 & 258,28 & & & \\
\hline
\end{tabular}

( $\mathrm{N}=$ Kişi sayısı, $\mathrm{X}=$ Aritmetik ortalama, $\mathrm{Ss}=$ Standart Sapma)

( $\mathrm{x}^{2}=$ Kruskal Wallis $\mathrm{H}$ testi Ki Kare değeri , $\mathrm{p}=$ percent kelimesinin kısaltması)

Çizelge incelendiğinde, katılımcıların ikamet yerleri bakımından ekoturizm kavramı algı düzeylerinin $(x 2=32,3 ; p<0,05)$, ekoturizm faaliyetleri bilgi düzeylerinin $(x 2=20,5 ; p<0,05)$ ve ekoturizm fayda bilgi düzeylerinin $(\times 2=21,6 ; p<0,05)$ anlamlı olarak farklılaştığı görülmektedir. Anlamlı farklılık bulunan ekoturizm kavramı algı düzeyinde, Isparta merkezde ikamet eden katılımcıların algı düzeyinin Isparta'nın ilçeleri ve diğer illerde ikamet eden katılımcılardan anlamlı düzeyde daha yüksek olduğu görülmektedir $(p<0,05)$. Anlamlı farklılık bulunan ekoturizm faaliyet bilgi düzeyinde, Isparta merkezde ve Isparta'nın ilçelerinde ikamet eden katılımcıların faaliyet bilgi düzeyinin diğer illerde ikamet eden katılımcılardan anlamlı düzeyde daha yüksek olduğu görülmektedir $(p<0,05)$. Anlamlı farklılık bulunan ekoturizm fayda bilgi düzeyinde, Isparta merkezde ikamet eden katılımcıların fayda bilgi düzeyinin diğer illerde ikamet eden katılımcılardan anlamlı düzeyde daha yüksek olduğu görülmektedir $(p<0,05)$ (Çizelge 23).

Çizelge 23. Katılımcıların ekoturizm kavramı algı ölçeği, ekoturizm faaliyet bilgi ölçeği ve ekoturizm fayda bilgi ölçeği puanlarının ikamet yerlerine göre karşılaştırılması

\begin{tabular}{|c|c|c|c|c|c|c|c|c|}
\hline Ölçek & İkamet Yeri & $\mathbf{N}$ & $x$ & Ss & Sira top. & $x^{2}$ & $\mathbf{p}$ & $\begin{array}{c}\text { Gruplar arası } \\
\text { fark }\end{array}$ \\
\hline \multirow{3}{*}{$\begin{array}{c}\text { Kavram } \\
\text { algı }\end{array}$} & Isparta merkez & 327 & 4,35 & 0,62 & 0,00 & \multirow{3}{*}{32,3} & \multirow{3}{*}{,000 } & \multirow{3}{*}{$1>2,1>3$} \\
\hline & Isparta'nın ilçeleri & 36 & 3,68 & 1,10 & 0,00 & & & \\
\hline & diğer iller & 46 & 3,90 & 0,83 & 0,00 & & & \\
\hline \multirow{3}{*}{$\begin{array}{c}\text { Faaliyet } \\
\text { bilgi }\end{array}$} & Isparta merkez & 327 & 4,20 & 0,57 & 0,00 & \multirow{3}{*}{20,5} & \multirow{3}{*}{,000 } & \multirow{3}{*}{$1>3,2>3$} \\
\hline & Isparta'nın ilçeleri & 36 & 4,20 & 0,50 & 0,00 & & & \\
\hline & diğer iller & 46 & 3,88 & 0,62 & 0,00 & & & \\
\hline \multirow{3}{*}{$\begin{array}{l}\text { Fayda } \\
\text { bilgi }\end{array}$} & Isparta merkez & 327 & 4,32 & 0,66 & 0,00 & \multirow{3}{*}{21,6} & \multirow{3}{*}{,000 } & \multirow{3}{*}{$1>3$} \\
\hline & Isparta'nın ilçeleri & 36 & 4,10 & 0,80 & 0,00 & & & \\
\hline & diğer iller & 46 & 3,89 & 0,86 & 0,00 & & & \\
\hline
\end{tabular}

( $\mathrm{N}=$ Kişi sayısı, $\mathrm{X}=$ Aritmetik ortalama, $\mathrm{Ss}=$ Standart Sapma)

( $\mathrm{x}^{2}=$ Kruskal Wallis $\mathrm{H}$ testi Ki Kare değeri , $\mathrm{p}=$ percent kelimesinin kısaltması)

Elde edilen bulgular sonucu, ankete katılanların ekoturizme yönelik algılarının yüksek olduğu, bunun yanında ekoturizm faaliyetlerine sıklıkla katıldıkları tespit edilmiştir. Katılımcıların ekoturizme genellikle bahar ve yaz aylarında, hafta sonlarında, öğleden önce ve öğleden sonraki saat dilimlerinde, 2-6 saat aralığında katıldığı tespit edilmiştir. Bunun yanında katılımcıların ekoturizme yönelik algılarının sahip oldukları demografik değişkenlere göre farklılıklar gösterdiği sonucuna ulaşılmıştır. 
Ekoturizm için en uygun etkinlikler doğa yürüyüşleri, bitki gözleme, dağa tırmanma, kampçılık, yaban hayvanı gözleme, kuş gözleme, orienteering (yön bulma), fotoğrafçılık ve tarihi ve arkeolojik geziler gibi etkinlikler olarak kabul edilmektedir (Selimoğlu, 2004; Gül ve Özaltın, 2007a; Gül ve Özaltın, 2007b; Gül ve Özaltın, 2008).

Nayir (2009) tarafından yapılan çalışmada Isparta yöresinde deneklerin en çok tercih ettikleri etkinlikler; doğa yürüyüşü (\%31), dağ tırmanışı (\%15), doğa-bitki gözlem ve inceleme (\%15), fotoğraf çekmek $(\% 13,5)$ gibi etkinlikler olduğu belirlenmiştir. Literatürdeki sonuçlar değerlendirildiğinde halkın ekoturizme yönelme nedenlerinin başında doğayla iç içe olma, stres atma, şehir gürültüsünden uzaklaşma, keşfetme, macera tutkusu ve rekreatif etkinlik yapma gibi amaçların geldiği görülmektedir (Karaküçük, 2008; Nayir, 2009; Taş, 2012).

Nayir (2009) tarafından Isparta yöresi için ekoturizm faaliyetlerinin etkin ve verimli olması için tanıtım ve reklam (\%28), eğitim ve bilinçlenme faaliyetleri $(\% 22,5)$, paydaşlarla yoğun işbirliği (\%17) vb konular önerilmiştir.

3.2. Isparta kentsel ekoturizmine yönelik mevcut durum tespiti (GZFT) ve analizilsparta kent insanına yapılan anket sonuçları ve yapılan envanter çalışmaları sonucu Isparta kentinin ekoturizm yönelik içsel faktörler olan "Güçlü ve Zayıf" yönleri ile dışsal faktörler olan "Fırsat ve Tehditler" konusunda tespitler yapılmış ve analiz edilmiştir (Çizelge 24, 25, 26 ve 27).

Çizelge 3.24. Isparta kent ekoturizmine yönelik güçlü yönleri

\section{Güçlü Yönler}

- Kent merkezi ve çevresinde açık ve yeşil alanlara (Ayazmana ve Gökçay Kent parkları, Milas mesire alanı, Gölcük Tabiat Parkı ve mahalle parkları) sahip olması

- Kentte alternatif turizm (doğa yürüyüşü, dağ bisikleti, tırmanış, yamaç paraşütü, balon vb.) etkinlikleri açısından zengin potansiyele sahip olması

- Her mevsim turizm imkânlarına sahip olması

- Kent merkezinde SDU ve ISUBU iki ayrı üniversitenin olması ve öğrenci sayısının fazla olması

- Yöreye özgü endemik bitki türlerine sahip olması (Örneğin Kasnak Meşesi=Quercus vulcanica)

- Kentin doğal ve kültür turizm potansiyeline ve sürdürülebilir turizm açısından otantik ve bozulmamış bir doğal bir çevreye sahip olması

- Kent merkezinde arkeolojik, tarihi ve kültürel değerlere (9 adet cami, 4 adet kilise, 4 adet hamam vb.) sahip olması

- Potansiyel Turizm merkezleri (Antalya, Pamukkale, İzmir, vb.) arasında geçiş bölgesi olarak kullanılması ve ulaşımın kolay olması

- Isparta kentinin Antalya turizm merkezine (128 km), Burdur kentine yakın olması (32 $\mathrm{km}$ )

- Ekoturizm için doğal kaynaklar ve bozulmamış doğal çevreye sahip olması

- Yaban hayatı açısından çeşitliliğe sahip olması (Gölcük gölünde kuş ve yaban hayatı gözlemciliği)

- Kent merkezinde mevcut konaklama tesislerinin (otel, pansiyon ve apart vb.) olmas

- Isparta kent merkezi ve çevresinde kültür rotaları ve kervan yollarının mevcut olması (Eğirdir Keyhüsrev Kervansarayı (Eğirdir Hanı), Gelendost Hanı (Kudret Hanı), St. Paul (Aziz Paul))

- İnanç ve kültür turizmi potansiyelinin gelişmiş olması 
- Kent merkezi ve çevresinde yerel işgücünün varlığı ve yerel ekonomik gelişme potansiyelinde olması,

- Kentin somut olmayan kaynak değerlerine sahip olması (Isparta gülü, halıcılık, elma vb. meyve yetiştiriciliği, gastronomi vb.)

- Tescilli Davraz kayak turizm alanı olması nedeniyle özellikle kış mevsiminde ziyaretçiler tarafından tercih edilmesi, Kayak merkezi çevresinde ekoturizm potansiyelinin olması

- Kent insanının turizme ve ekoturizme karşı olumlu tutumu ve yaklaşımının olması vb.

- Illk, orta ve lise öğrencilerinin varlığı ve potansiyeli

- Kentin Tarihsel ve kültürel dokusuyla Orta Anadolu'nun merkezinde olması, şehrin 4500 yaşında tarihi bir geçmişi olması

- Misafirperver, hoşgörülü yerel insan kaynağı

Çizelge 25. Isparta kent ekoturizmine yönelik zayıf yönleri

\section{Zayıf Yönler}

Toplam Toplam puan

Puan yüzde oranı

- Ekoturizm rotaların (kısa, orta ve uzun mesafeli) olmaması ve projelendirilmemesi

- Alanın bütüncül olarak etkin ve yetkin olan bir Yönetim Birimi ve organizasyonun olmaması

- Kurumlar arası iletişim ve koordinasyon eksikliği

- Tur organizasyonlarının eksikliği

- Ekoturizm etkinliklerine yönelik kaynak değerlerinin envanterinin yetersiz olması ve CBS ortamında veri tabanının oluşturulmaması

- Uluslararası ve ulusal ölçekte tanıtım eksikliğinin olması

- Ekoturist rehberi olmaması

- Yönlendirici, özendirici destek ve teşviklerin yokluğu

- Otantik ve ekoturizm odaklı çevreci konaklama imkânlarının yetersiz olması

- Yatırım ve finans imkânlarının yetersiz olması,

- Turistik ürün arzının yetersiz, ürün çeşitliliğinin olmayışı

- Ekoturizm ürünlerinin tanıtım ve pazarlama eksikliği

- Mimari ve peyzaj mekânsal tasarım uygulama projelerinin olmaması

- Ekoturizm etkinlikleri için eğitimli kalifiye eleman eksikliği

- Kente özgü stratejik eylem planının veya özel bir koruma ve yönetim planının olmaması

- Tarihi yerlerinin ve eserlerin yöre insanları tarafından bilinçsizce ve amaç dışı kullanımı

- Yerel yönetimlerin ilgisizliği

- Alanda ziyaretçi yönetim planının olmaması

- Mevcut konaklama ve hizmet sektöründeki ücretlerinin yüksek olması ve her kesime hitap etmemesi

- Ekoturizm eğitimi ve bilincinin eksikliği

- Toplu ulaşım ve taşıma hizmetlerinin yetersizliği 
Çizelge 26. Isparta kent ekoturizmine yönelik fırsatlar

\begin{tabular}{lcc}
\multicolumn{1}{c}{ Fırsatlar } & $\begin{array}{c}\text { Toplam } \\
\text { Puan }\end{array}$ & $\begin{array}{c}\text { Toplam puan } \\
\text { yüzde oranı }\end{array}$ \\
\hline $\begin{array}{l}\text { - Ulusal Turizm 2023 Stratejik Planlamasında Göller Bölgesinin ekoturizm } \\
\text { bölgesi olarak belirlenmesi }\end{array}$ & 141 & 1,75 \\
- Doğa ve ekoturizme olan ilginin artması, & 140 & 1,73 \\
- Uluslararası potansiyel turizm merkezleri (Antalya, Pamukkale, İzmir, & & 1,72 \\
& Aydın vb.) arasında geçiş bölgesinde yer alması ve turizm potansiyeline \\
katkıda bulunması & 139 & 1,71 \\
- Turizm Acente ve Yatırımcılarının ilgi göstermesi & 138 & 1,66 \\
- Antalya kent merkezine ve havaalanına yakın olması, & 134 & 1,52 \\
- Yöre insanlarının alanın öneminin farkında olması ve aktif rol üstlenme & & 1,42 \\
& eğiliminde olması, & 123 \\
- Spor takımlarının yaz kamplarına yönelik taleplerin olması, & 115 & 1,39 \\
\hline
\end{tabular}

Çizelge 27. Isparta kent ekoturizmine yönelik tehditler Tehditler

- Doğal ve Kültürel turizm mekanlarının taşıma kapasitesinin çok üzerinde kullanılması durumunda ekolojik veya çevresel bozulma riskinin olması,

- Yerel ekonomik kaynakları ve istihdam olanaklarının kısıtılığı

$\begin{array}{ll}138 & 1,71 \\ 131 & 1,62 \\ 130 & 1,61 \\ 127 & 1,57 \\ & \\ 125 & 1,55 \\ 114 & 1,41 \\ 110 & 1,36 \\ 109 & 1,35 \\ 109 & 1,35\end{array}$

- Turizm amaçı kullanılabilecek alanlarda başka arazi kullanım taleplerinin olması

- Dış yatırımcıların turizm amaçlı mimari yapıları satın alma eğilimleri

- Küresel iklim değişikliği nedeniyle doğal bitkiler ve yaban hayatına olumsuz etkileme olasılığı

- Yaban hayatı açısından bilinçsiz ve kaçak avlanmanın yapılması

- Bilinçsiz tarım ve hayvancılık faaliyetleri

- Doğal alanlarda kontrolsüz çevre bozulmaları olasılığı

- Arkeolojik alanlarda yapılan tahribat

Durgun (2007), GZFT analizi ile Isparta turizminin en güçlü yönünün; zengin tarihi, kültürü ve bozulmamış doğal değerlerinin olduğu ifade etmiştir. Isparta turizminin en zayıf yönünün ise; tanıtım ve pazarlama eksikliği, yeterince gelişmemiş turizm bilinci ve yerel yönetimlerin ilgisizliği olduğunu belirtilmiştir. İlin alternatif turizm türleri için potansiyelinin yüksek olması il turizminin en büyük fırsatı olarak belirtilirken, kentin turistik imajının zayıf olması Isparta turizminin en büyük tehdit unsuru olarak belirtilmiştir.

Nayir (2009)’a göre Isparta Yöresinin ekoturizm açısından Güçlü yönleri; Isparta coğrafyasının iklimsel ve jeomorfolojik konumunun çeşitliliği ve zenginliği, bitki ve yaban hayvan tür ve genetik çeşitliliği ve zenginliği, tarihi, arkeolojik, dinsel ve folklorik kültürel değerler açısından zenginliği ve doğal alanlarla bir arada yer alması, Antalya'ya yakın mesafede ve ulaşılabilir olması, her mevsimde farklı turizm veya ekoturizm etkinliklerinin yapılabilmesi, turizm ve ekoturizm yönünden çeşitlendirilmiş yöresel ürünlerin varlığı gibi sıralanmıştır. Isparta yöresinin zayıf yönleri; ekoturizm etkinliklerin alansal ve noktasal eylem planlarının olmaması, doğal alanlarda yapılan ekoturizm etkinliklerinin koordinasyon, organizasyon, izleme ve denetlemeye yönelik kurumsal bir yapı veya faaliyetlerin olmaması, ekoturizm paydaşları (alan yöneticileri, ekoturistler, acenteler, yöre insanları gibi) arasında diyalog ve işbirliğinin kurumlaşmamış olması ve katılım mekanizmalarının eksikliği, ekoturizm etkinliklerine yönelik tanıtım, reklam ve pazarlama imkânlarının yetersizliği, Isparta kentinin turistik kimlik ve imajının zayıf olması, finansman, yatırım teşvikleri ve girişimciliğin yetersizliği vb. şeklinde sıralanmıştır. Dışsal faktör olarak fırsatlar; Alternatif turizm türleri için potansiyelin yüksekliği, kırsal 
alanda yerel halka yeni iş ve gelir fırsatının sağlama olanağı, Isparta SDÜ öğrenci ve öğretim eleman kapasitesinin varlığı gibi şeklinde belirtilmiştir. Dışsal faktör olarak tehditler ise; Doğal alanda yapılan ekoturizm faaliyetlerinin kontrolsüz ve bilinçsizce yapılması sonucu biyolojik çeşitliliğin olumsuz etkilenmesi, ekoturizm amaçlı işletmecilerin veya yatırımcıların getirim (rant) ve kar uğruna kırsal yöre insanlarını izole ederek, tek paydaş olma yaklaşımı ve ekoturizme yönelik bilinçsizce yapılacak teşvik ve yatırımların doğal alanlarda aşırı yapılaşmaya yol açması gibi şeklinde belirlenmiştir (Nayir, 2009).

Durgun (2007)'a göre ise Isparta turizminin en zayıf yönü tanıtım ve pazarlama eksikliği olup aynı zamanda turizm bilincinin gelişmemiş olması, yerel yönetimlerin ilgisizliği ve bununla bağlantılı olarak ta alt yapı ve hizmet kalitesinin yetersizliği ve turistik bir imajının olmamasıdır.

\section{Sonuç ve Öneriler}

Günümüz koşullarında kent insanlarının yaşam ve davranış eğilimleri değişmekte ve çeşitlenmekte olup özellikle kentsel turizm aktivitelerinin önemi daha da artmaya devam etmektedir. Kent insanlarının ve turistlerin beklentileri ve talepleri doğrultusunda şehirler yeni eğilimleri takip etmek zorunda kalmaktadır. Örneğin günümüzde yaşanan pandemi (Covid 19) nedeniyle kent insanlarının evlerinde uzun süre kalması ve seyahat sınırlamaların getirilmesi vb nedenler sonucu kent içi ve yakın çevresindeki doğal ve kültürel rekreasyon alanlarına olan talebi ve kullanımını daha da artırmıştır. Kentsel ekoturizm, insanları kentsel bir çevrede doğa ile iç içe olma, keşfetme ve doğa farkındalığını artırma bağlamında önem kazanmaya başlamıştır. Kentsel ekoturizmi, kent doğal ekosistemine saygı duyan bir turizm anlayışı olup kentin doğal ve kültürel kaynak değerlerinin keşfedilmesi ve gezilmesi olarak kabul edilmektedir (Urban Ecotourism Declaration (UED), 2006).

Kentsel ekoturizm kentin ekolojik ve kültürel miras değerlerinin sürekliliğini koruyarak, kente ve kent insanına ekolojik ve ekonomik gelişme imkanı sağlayan, insanların farkındalık ve bilinç düzeyini artıran kente uygun ekoturizm faaliyetleri ve politikası olarak tanımlanmaktadır (Joppe ve Dodds, 1998; Wu, Wang ve Ho, 2010; İşci, Pınarcı ve Gül, 2018). Kentsel ekoturizmin bileşenleri, yerel katılımcılık, yerel gelişme (ekonomik, sosyo kültürel ve ekolojik) ve politikalar, ekolojik odaklı yaklaşım, koruma ve geliştirme, sürdürülebilirlik, eğitim (farkındalık ve bilinçlenme) ve tanıtım olarak özetlenebilir.

Kentsel ekoturizmin temel ilkeleri ise şu şekildedir.

- Doğal ve kültürel temelli olması,

- Kentin doğal ve kültürel değer ve çeşitlerinin korunması ve yaşatılması,

- Ekolojik sürdürülebilirliğin sağlanması,

- Bütüncül katılımcılık: Yerel yönetim ve yöneticileri, plancılar, karar vericiler, STK, resmi kurum ve kuruluşlar, vb. kentin tüm paydaşlarının kentsel ekoturizm tüm süreçlerine dâhil olması ve iş birliğinin ve koordinasyonun sağlanması hedeflenir.

- Doğa ve çevre koruma farkındalık ve bilinçlenmenin artırılması,

- Kent yerelinde ekolojik, sosyal ve ekonomik yarar sağlanması,

- Ekoturistlerin ve kent insanının sorumluluk alması, takdir etmesi ve tatmin düzeyinin yüksek olması,

- Kentin yönetim politikaları ile uyumlu olması,

- Ekoturizm yatırımlarının daha çok kent ölçeğinde küçük ve orta işletmeler tarafından yapılması ve teşvik edilmesi,

- Kentsel ekoturizm bağlamında oluşturulacak ekoturizm rotalar, planlama/tasarım ve yönetim süreçleri bütüncül olarak organize edilmesi vb. şeklinde açıklanabilir.

Bu çalışmada anket sonuçlarına göre katılımcıların ekoturizmi tercih etme nedenleri doğayı keşfetme, rekreasyonel etkinlik yapma isteği, kendini keşfetme isteği, insanlarla tanışma, kültür gezisi, macera tutkusu yaşama, sessiz ortam isteği, bilimsel ve sosyal merak ve koruma amaçlı özgün yerleri görme 
olarak sıralanmıştır. Ekoturizm faaliyetlerinin katılımcılara başta mutlu etmesi, doğadaki canlılarla yakın iletişim kurulması, yaşama sevinci sağlaması, insanlarla sağlıklı iletişim kurmaya yardımcı olması, doğayı anlamaya yönelik birçok katkılar sağladığı belirtilmiştir. Katılımcıların çoğunluğu ekoturizm etkinlikleri olarak doğa yürüyüşü, dağ bisikleti gezme, fotoğraf çekmek, bitki gözleme, tarihi ve antik yerlere geziler, gül toplama ve üretim faaliyetlerini öncelikli olarak tercih edildiği belirlenmiştir. Katılımcıların çoğu ekoturizm etkinlikleri için kent parkları ve diğer kentsel açık ve yeşil alanların uygun olabileceği ifade edilmiştir. Katılımcıların kentsel ekoturizm faaliyetleri için çoğunlukla haftada bir kez gerçekleştirebileceğini, en çok mayıs, nisan ve haziran aylarını tercih ettikleri, cumartesi ve pazar günlerinin daha uygun olacağı, genel olarak öğleden önce faaliyetlerin yapılabileceği ve faaliyetler için yaklaşık 4-6 saat zaman ayırabileceğini ifade etmiştir.

Bu çalışmada yapılan GZFT analizi ile kentsel ekoturizm açısından Isparta kent merkezinin önemli potansiyele sahip olduğu belirlenmiştir. Kent merkezi ve çevresinde kültürel ve doğal değerler önemli bir yer teşkil etmektedir. Ancak bu güçlü yönlerinin veya değerlerin kentsel ekoturizm açısından değerlendirilebilmesi için zayıf yön olarak belirlenen konularda neden sonuç ilişkisine göre eylemler öngörülmeli ve uygulanmalıdır. Tehdit olarak belirtilen konularda ise fırsata dönüştürecek şekilde eylemler ortaya konulmalı ve güçlü yönler sürdürülebilir ve uygulanabilir hale getirilmelidir.

Isparta kentsel ekoturizm için dikkate alınması gereken öneriler;

- Isparta kent merkezinde kentsel ekoturizm için Isparta il Kültür ve Turizm Müdürlüğü sorumluluğunda Isparta Belediyesi, Orman Bölge Müdürlüğü, Üniversite, BAKA, Ekoturizm acenteleri, Rehberler vb ile ilgili paydaşlarla ortak hareket ederek sinerji ve işbirliği oluşturulmalıdır. Kentsel ekoturizm faaliyetleri için sorumlu bir birim veya komisyon oluşturulmalıdır.

- Yapılacak olan kentsel ekoturizm stratejik eylem planı ile uygulama, kontrol, denetleme ve yönetişim sağlanmalıdır.

- Kentsel ekoturizm için kullanılabilecek mekânsal değerlerin peyzaj tasarım uygulama projeleri yapılmalıdır. Mevcut mekânların bakım, onarım ve geliştirmeye yönelik çalışmalar öngörülmelidir.

- Kentsel ekoturizm için öncelikle kentsel yeşil alanlar (kent ve mahalle parkları vb) değerlendirilmelidir.

- Ekoturizm etkinlikleri kentin doğasına ve ekolojik/çevresel yapısına katkı sağlayacak programlar, eğitsel etkinlikler ve organizasyonlar gerçekleştirilmelidir.

- Ekoturizm etkinlikleri ve rotalar, yerel halkı ve ziyaretçileri kapsayacak şekilde çok yönlü olarak düşünülmelidir.

- Kentsel ekoturizmi etkinlikleri için gerek kent insanı gerekse turistler için yazılı ve görsel materyaller hazırlanmalı, ulusal ve uluslararası ölçekte tanıtımı yapılmalıdır.

- Isparta kent merkezi ve çevresine yönelik ekoturizm ve kültür rotaları yapılmalı ve diğer kültür rotaları ile bütünleştirilmelidir. Anket sonuçlarına göre Katılımcıların çoğunluğu 5-10 $\mathrm{km}$ arası (\%35) ve 10-15 km arasında (\%27) olmasını istemektedir. Bu bağlamda kısa mesafeli rotalar $5 \mathrm{~km}$, orta mesafeli rotalar $10 \mathrm{~km}$ ve uzun mesafeli rotalar ise $15-30 \mathrm{~km}$ olacak şekilde kurgulanmalıdır.

- Isparta kentsel ekoturizm stratejisi kentin kimlik değerleri ile ilişkilendirilerek yapılmalıdır.

- Ekoturizm faaliyetleri için "Ekoturizm Rehberlik Sertifikasyon" kursları düzenlenmelidir.

- Kentsel ekoturizm faaliyetleri için finans kaynağı oluşturulmalıdır.

Son söz olarak; Isparta kent merkezinin sahip olduğu kültürel ve doğal değerler, kentsel ekoturizm açısından önemli bir potansiyele oluşturmaktadır. Bu potansiyelin değerlendirilmesi kapsamında yapılacak her türlü girişim veya eylemler kentin sürdürülebilir gelişimine ve kaynak değerlerin korunmasına büyük katkılar sağlayacaktır. Bu eylemler bir yandan kent insanının farkındalığını ve bilinçlenmesini artırabileceği gibi diğer yandan daha fazla turistin kente gelmesine, kentin tanıtımına ve gelişimine önemli fırsatlar oluşturabilecektir. 


\section{Teşekkür ve Bilgi Notu}

Bu makale, Süleyman Demirel Üniversitesi Fen Bilimleri Enstitüsü Peyzaj Mimarlığı Anabilim Dalı’nda, 2020 yılında tamamlanan doktora tezinden üretilmiştir. Makalede, ulusal ve uluslararası araştırma ve yayın etiğine uyulmuştur. Çalışmada Etik Kurul izni gerekmemiştir.

\section{Kaynaklar}

Akdemir, S. (2008). XVIII. Yüzyılın İlk Yarısında Isparta, Isparta Valiliği il Kültür ve Turizm Müdürlüğü Yayınları: 2, Isparta.

Baş, T. (2006). Anket, Seçkin Matbaası. S: 230.

Bekdemir, Ü. ve Elmacı, S. (2014). Giresun İlinin Eko-Turizm Potansiyeli ve Değerlendirme Olanakları. Karadeniz Sosyal Bilimler Dergisi, Karadeniz Özel Sayısı (6), 1-30.

Blackstone Corporation. (1996). Developing an urban ecotourism strategy for Metropolitan Toronto: A feasibility assessment for the green tourism partnership Toronto Green Tourism Association, Toronto.

Böcüzade, Ş. S. (1983). Kuruluşundan Bu Güne Kadar Isparta Tarihi, c: 1-2, haz: S. Seren, Serenler Yayınları, İstanbul.

Buckley, R. (2013). Defining Ecotourism: Consensus on Core, Disagreement on Detail. İçinde Roy Ballantyne and Jan Packer (Edt.), International Handbook on Ecotourism (ss.9-14). UK: Edward Elgar Publishing.

Cosmescu, I. ve Cosmescu, D. (2007). The Ecotourism-A Strategic Alternative for Contemporany Tourism. Annals of the University of Petroşani, Economics, 7, 65-72.

Durgun, A. (2007). Isparta turizminin swot analizi. Süleyman Demirel Üniversitesi Sosyal Bilimler Enstitüsü Dergisi Yıl/Volume: 3, Sayı/Issue: 5, 2007, 93-109.

Gheorghe, A. ve Udrescu, M. A. (2018). Management Model of Ecoturism Services Quality Analize. Romanian Statistical Review, 2, 119-136.

Gül, A. ve Küçük, V. (2001). Kentsel açık-yeşil alanlar ve isparta örneğinde irdelenmesi. Süleyman Demirel Üniversitesi Orman Fakültesi Dergisi, A(2), 27-48.

Gül, A. ve Özaltın, O. (2007a). Türkiye'deki korunan doğal alanlarda ekoturizm amaçlı ekolojik planlama yaklaşımı. Ekolojik Mimarlık ve Planlama Ulusal Sempozyumu, 27-28 Nisan-2007, Antalya Mimarlar Odası. 194-203s. Antalya.

Gül, A. ve Özaltın, O. (2007b). Ekoturizm ve Isparta I. Gülçevrem, Isparta il Çevre ve Orman Müdürlüğü, Yıl 2007/2 Sayı:2 ISSN-1307-6795. 22-25s. Isparta.

Gül, A. ve Özaltın, O. (2008). Ekoturizm ve Isparta II. Gülçevrem, Isparta İ Çevre ve Orman Müdürlüğü. 2008/1 Sayı:3 ISSN-1307-6795. 18-21s. Isparta.

İşci, B., Pınarcı, N. ve Gül, A. (2018). Kentsel ekoturizm ve isparta kent merkezinde uygulanabilirliği. Sosyal Bilimler Enstitüsü Dergisi. (Urban Ecotourism and Applicability in Isparta City) 2018 Cilt 8, Sayı 1:sayfa 101-115. ISSN: 2147-7841.Doi Number: http://dx.doi.org/10.14230/joiss481.

Joppe, M. ve Dodds, R. (1998). The urban green tourism: applying ecotourism principles to the city. Travel and Tourism Research Association- Canada, Toronto. Retrieved from http://www.csu.edu/cerc/researchreports/documents/UrbanGreenTourism1998.pdf

Kaplan, S. (2013). Community Based Ecotourism for Sustainable Development in Eastern Black Sea Region an Evaluaion Through Local Communities Tourism Perception. Yayımlanmamış Yüksek Lisans Tezi, Orta Doğu Teknik Üniversitesi Sosyal Bilimler Enstitüsü, Ankara.

Karaküçük, S. (2008). Rekreasyon: Boş Zamanları Değerlendirme. Altıncı Baskı. Gazi Kitabevi. 
Kasalak M. (2015). Dünyada ekoturizm pazarı ve ekoturizmin ülke gelirlerine katkıları. Journal of Recreation and Tourism Research, 1(2): 20-26.

Nayir, O. (2009). Isparta Yöresi Korunan Doğal Alanlarında Ekoturizm Talep Ve Eğilimlerinin Belirlenmesi Yüksek Lisans Tezi, T.C. Süleyman Demirel Üniversitesi, Fen Bilimleri Enstitüsü, Peyzaj Mimarlığı Anabilim Dalı, Isparta, 116s.

Selimoğlu, Ö. (2004). Dünya ve Türkiye'de Ekoturizm. İstanbul Ticaret Odası Etüt ve Araştırma Şubesi, 19 s, ìstanbul.

Taş, S. (2012). Trabzon ve Ekoturizm: Yerli Ziyaretçilerin Yöreyi Değerlendirmesine Yönelik Bir Araştırma. Balıkesir Üniversitesi, Sosyal Bilimler Enstitüsü, Yüksek Lisans Tezi, s177, Balıkesir.

Urban Ecotourism Declaration. (UED). (2006). Retrieved 18.05.06, http://www.planeta.com/ ecotravel/tour/urbandeclaration.html.

Wu, Y.Y., Wang, H.L. ve Ho Y.F. (2010). Urban ecotourism: Defining and assessing dimensions using fuzzy number construction. Tourism Management 31:739-743. 